\title{
POWER GENERATOR FROM OCEAN WAVE ENERGY CONVERSION
}

\author{
Widi Aribowo \\ Fakultas Teknik, Program Studi Teknik Elektro \\ Universitas Negeri Surabaya \\ Email: widiaribowo@unesa.ac.id \\ Achmad Imam Agung \\ Fakultas Teknik, Program Studi Teknik Elektro \\ Universitas Negeri Surabaya \\ Email: achmadimam@unesa.ac.id \\ Subuh Isnur Haryudo \\ Fakultas Teknik, Program Studi Teknik Elektro \\ Universitas Negeri Surabaya \\ Email: subuhisnur@unesa.ac.id \\ Syamsul Muarif \\ Fakultas Teknik, Program Studi Teknik Elektro \\ Universitas Negeri Surabaya \\ Email: syamsulmuarif16050874034@mhs.unesa.ac.id
}

\begin{abstract}
ABSTRAK
Kebutuhan energi listrik semakin meningkat setiap tahunnya. Di sisi lain, pembangkit listrik terbesar di Indonesia masih menggunakan sumber energi tidak terbarukan seperti batubara dan minyak bumi, sedangkan sumber energi tidak terbarukan tersebut pada akhirnya akan habis. Untuk mengantisipasi habisnya energi ini, diperlukan sumber energi terbarukan. Keberadaan ini tidak akan habis meski dikonsumsi setiap hari. Energi terbarukan yang dapat dimanfaatkan untuk diubah menjadi energi listrik di wilayah pesisir adalah tenaga ombak. Ombak yang selalu menghempas di bibir pantai bisa dimanfaatkan untuk menggerakkan turbin. Turbin berputar karena hempasan ombak terhubung ke generator DC. Ini akan mengubah energi mekanik menjadi energi listrik. Energi listrik yang dihasilkan oleh generator DC digunakan untuk mengisi baterai. Tujuan dari penelitian ini adalah untuk mengetahui bagaimana merancang pembangkit listrik tenaga ombak dan untuk mengetahui kinerjanya. Metode eksperimen digunakan dalam penelitian ini. Hasilnya, generator bekerja optimal pada siang hari dengan tegangan yang dihasilkan 10,6V hingga 10,7V dengan kecepatan putaran 623 Rpm hingga 710 Rpm.
\end{abstract}

Kata kunci: pembangkit listrik, energi ombak, energi laut, generator dc, energi terbarukan

\section{ABSTRACT}

The need for electrical energy has increased every year. On the other hand, the largest power plants in Indonesia still use non-renewable energy sources such as coal and petroleum, while these non-renewable energy sources will eventually run out. To anticipate running out of this energy, a renewable energy source is needed. This existence will not run out even though it is consumed every day. Renewable energy that can be used for conversion into electrical energy in coastal areas is wave power. The waves that always crash on the shoreline can be used to drive turbines. The turbine rotates due to the crashing waves connected to a DC generator. It will convert mechanical energy into electrical energy. The electrical energy generated by the DC generator is used to charge the battery. The purpose of this research is the know-how to design a wave power generator and to determine the performance. The experimental method is used in this study. In the results, the generator works optimally during the day with the resulting voltage of $10.6 \mathrm{~V}$ to $10.7 \mathrm{~V}$ with rotation speed of $623 \mathrm{Rpm}$ to $710 \mathrm{Rpm}$. 
Keywords: power generator, wave energy, ocean energy, generator $d c$, renewable energy

\section{INTRODUCTION}

Abundant energy sources are marine energy and geothermal energy. There are several types of ocean energy, namely waves, tides, heat gradients and salinity gradients. All of this energy is renewable. Another form of solar energy is ocean energy in the form of waves, tides, and ocean heat. Whereas tides are the effects of bum-moon gravitational interactions. Geothermal energy comes primarily from radioactive decay deep within the earth and residual heat from the formation of the earth.

Ocean wave energy is a combination of potential and kinetic energy in moving water and the height of the waves. Tides is the kinetic energy from the movement of water. While ocean thermal energy is energy caused by differences in water temperature on the warm surface and cold water inside.

Electrical energy in Indonesia is an increasing need every year followed by economic growth which has also increased. In 2018 Indonesia requires electricity of 232,416 MWh and in 2019 it will increase to 247,416 MWh [1].

Almost all of Indonesia's generators are use non-renewable natural energy sources, such as coal and petroleum, where these energy sources will continue to decrease every year or even run out [2]. To overcome energy exhaustion, it is necessary to use renewable energy that can meet the needs of electrical energy. In Indonesia, renewable energy sources are very large, including solar power, wind power, wave power, and geothermal power [3].

One of the renewable energies that can be utilized is waves. This can be utilized by converting waves into electrical energy. This takes advantage of the waves to drive a turbine that can drive a generator. Generator converts wave energy into electrical energy.

This research will make a prototype of a power plant using wave power. In this experiment, the wind speed will be measured. in addition, this study also measures the voltage and current generated. wind speed greatly affects the speed of the waves crashing.

\section{METHOD}

The methodology used is through measurement and direct observation of turbine testing in Talang Siring, Montok Village, Larangan District, Pamekasan Regency. The speed of ocean currents that occur every day is the result of tidal conditions under the influence of gravitational force. In this research, the implementation process pays attention to numerical data and then displays it using graphs, tables and figures [4]. The technique used in data collection is the observation method. Systematic recording and direct observation of the data required for research is an observational method.

This design tool uses SketchUp software. the next step is to collect the tools and materials needed to make the prototype. It is used for hardware design. The next stage is hardware testing. If the appliance can generate voltage, generate current and charge the battery. The stage continues to the stage of data collection. However, if the device is unable to generate voltage, current and charge the battery. So, the step back to the previous one is to design and repair the tool. Finally, the data obtained were analyzed. Figure 1 is the design of the tool you want to design and the size of the tool. 


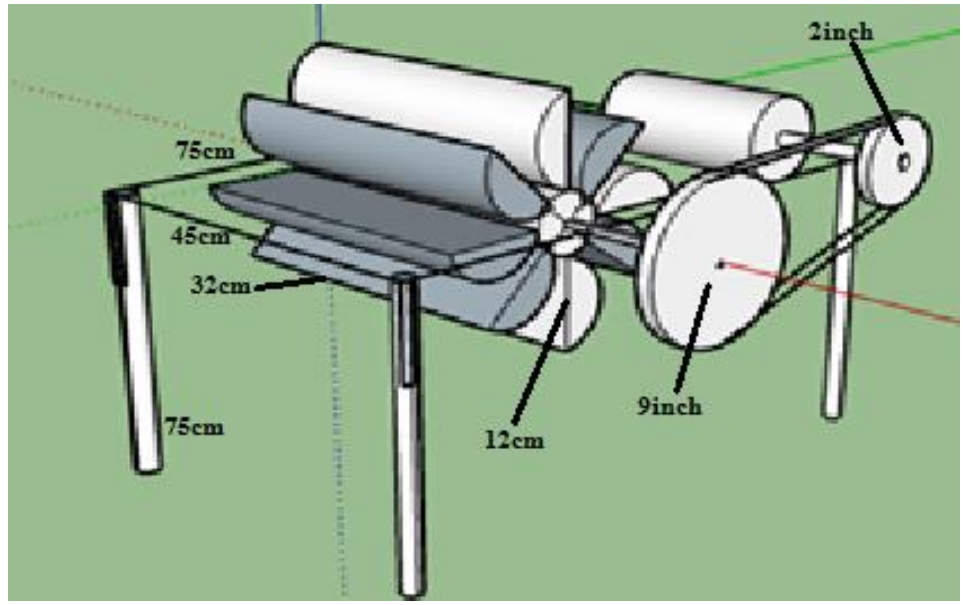

Figure 1. Hardware Design

Figure 1 is the design of the tool you want to design and the size of the tool. As shown in Figure 1, the design of this tool uses two pulleys. The first pully connected to a generator with a small size with a diameter of 2 inches. The second pully is connected to a water turbine with a diameter of 9 inch, and the two pulleys are connected to each other by a fanbelt. The function of the generator in Figure 1 is to convert mechanical motion energy into voltage and current. The turbine has the function of converting the wave motion into mechanical rotation. Pully and fanbelt have a function as a link between the turbine and the generator to move the rotation of the turbine to the generator. The generator used has the following specifications:

Tabel 1. Generator Specifications

\begin{tabular}{ccc}
\hline Parameter & Value & Unit \\
\hline Voltage & 12 & Volt \\
Speed & 1600 & Rpm \\
Current & 40 & Ampere \\
Power & 480 & Watt \\
\hline
\end{tabular}

In the figure 1, the turbine is $12 \mathrm{~cm}$ in diameter by $32 \mathrm{~cm}$ in length. So, the outside cross-section of the turbine is $384 \mathrm{~cm}$. In Table 1, the generative voltage is $12 \mathrm{~V}$ with a rotation of $1600 \mathrm{Rpm}$ and a current of $40 \mathrm{~A}$ with a power of 480 Watts. Figure 2 is an energy conversion flow. This starts from the turbine being hit by the waves to the energy storage stage of the battery. 


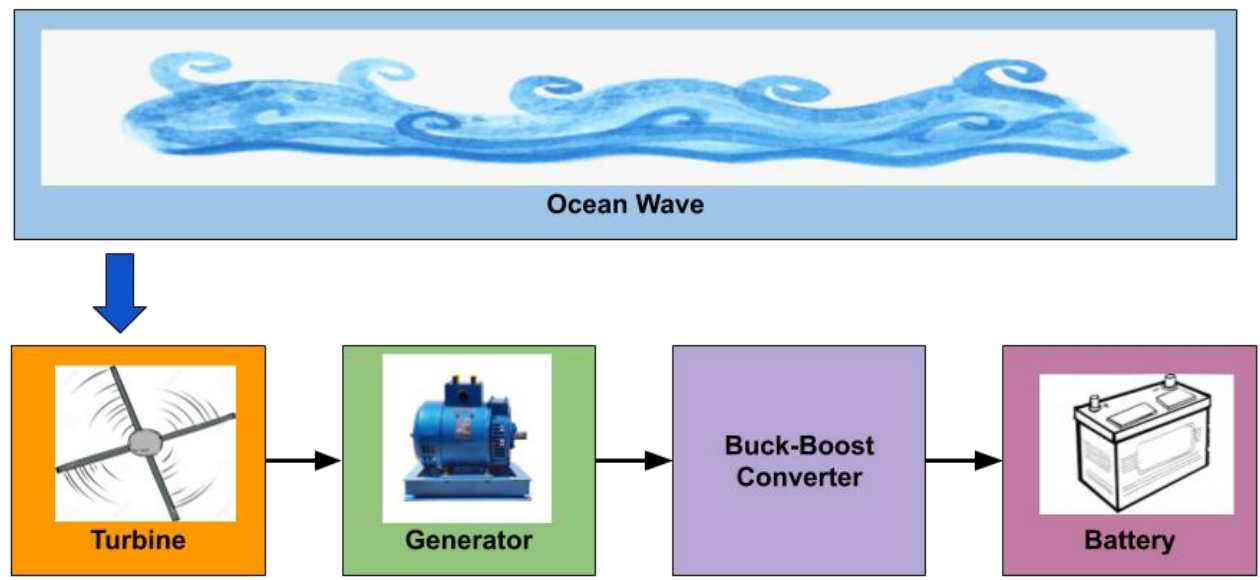

Figure 2. Wave Power Generation System Diagram

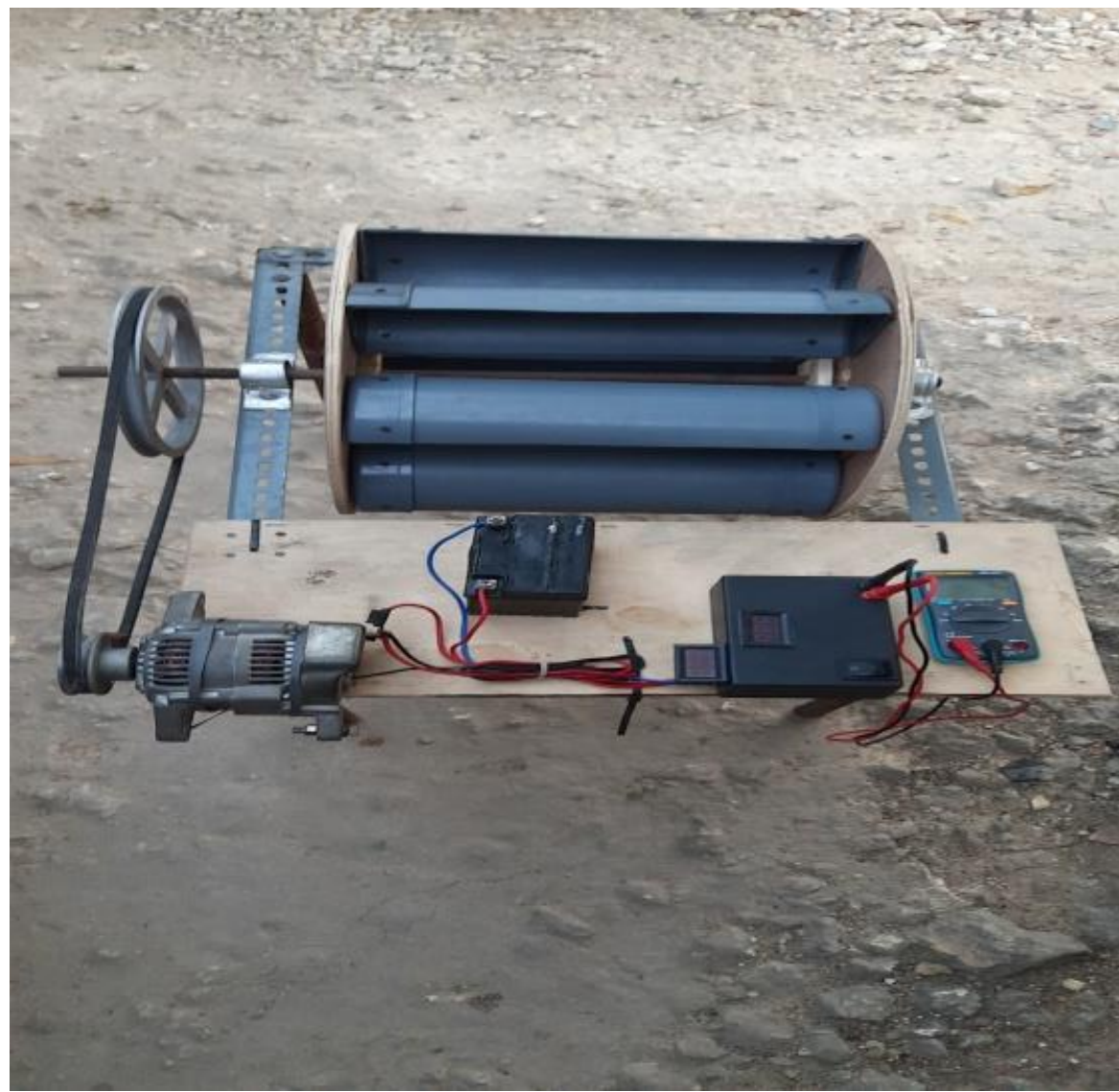

Figure 3. Wave Power Plant Design

In Figure 3, the tool to be used is $75 \mathrm{~cm}$ long by $45 \mathrm{~cm}$ wide and $75 \mathrm{~cm}$ high. The DC generator is connected to the turbine using a fanbelt and two pulleys. If there are waves coming, they will hit the turbine blades and the turbines will spin. The turbine drives the connected pully and drives the DC generator in the generator. Furthermore, the generator will convert the mechanical energy of motion into electrical energy 
and the electrical energy is used to charge the battery. The measuring instrument used in this tool is an ampere meter which functions to measure currents from 0-10A. The voltmeter has a function to measure the output voltage of the generator with a voltage measurement limit from $0-100 \mathrm{~V}$, and the tachometer has a function to measure the rotation speed of the generator. Data were collected by measuring the output voltage of the generator, the battery charging current and the generator rotation speed which was carried out for 3 days. Everyday data collection is carried out from 08.00-16.00. The time for charging the battery can be seen from the following equation:

$$
T=\left(\frac{C}{I}\right)+\left(20 \% \cdot\left(\frac{C}{I}\right)\right)
$$

Where $\mathrm{T}$ is Long time charging the battery (hours). Battery Capacity (Ah) is C. Battery Charging Current (A) is I.

\section{RESULT AND DISCUSSION}

Table 2 shows the results of the tool testing on the first day.

Table 2. Test Results on The First Day

\begin{tabular}{ccccc}
\hline Time & $\begin{array}{c}\text { Voltage } \\
\text { Output } \\
\text { Generator }\end{array}$ & $\begin{array}{c}\text { Voltage Output } \\
\text { Buck-Boost } \\
\text { Converter }\end{array}$ & $\begin{array}{c}\text { Speed Of } \\
\text { Generator }\end{array}$ & $\begin{array}{c}\text { Current } \\
\text { Generator }\end{array}$ \\
\hline 08.00 & $8.2 \mathrm{~V}$ & $13.8 \mathrm{~V}$ & $524 \mathrm{Rpm}$ & $430 \mathrm{~mA}$ \\
09.00 & $8,0 \mathrm{~V}$ & $13,8 \mathrm{~V}$ & $497 \mathrm{Rpm}$ & $415 \mathrm{~mA}$ \\
10.00 & $8,8 \mathrm{~V}$ & $13.8 \mathrm{~V}$ & $590 \mathrm{Rpm}$ & $520 \mathrm{~mA}$ \\
11.00 & $9,1 \mathrm{~V}$ & $13,8 \mathrm{~V}$ & $637 \mathrm{Rpm}$ & $572 \mathrm{~mA}$ \\
12.00 & $10.6 \mathrm{~V}$ & $13,8 \mathrm{~V}$ & $732 \mathrm{Rpm}$ & $610 \mathrm{~mA}$ \\
13.00 & $10.7 \mathrm{~V}$ & $13.8 \mathrm{~V}$ & $693 \mathrm{Rpm}$ & $618 \mathrm{~mA}$ \\
14.00 & $10 \mathrm{~V}$ & $13,8 \mathrm{~V}$ & $710 \mathrm{Rpm}$ & $596 \mathrm{~mA}$ \\
15.00 & $9.5 \mathrm{~V}$ & $13,8 \mathrm{~V}$ & $684 \mathrm{Rpm}$ & $520 \mathrm{~mA}$ \\
16.00 & $8,5 \mathrm{~V}$ & $13,8 \mathrm{~V}$ & $534 \mathrm{Rpm}$ & $490 \mathrm{~mA}$ \\
\hline
\end{tabular}

In Table 2, it can be seen that the maximum result of the tool testing on the first day is at 13:00 with the resulting voltage of $10.7 \mathrm{~V}$ with a generator rotating speed of $693 \mathrm{Rpm}$ and a large current flowing of $618 \mathrm{~mA}$. Testing tools on the second day can be seen in Table 3. Maximum results are at 14.00 with the resulting voltage of $10.6 \mathrm{~V}$ with a generator rotating speed of $515 \mathrm{Rpm}$ and a current flowing of $613 \mathrm{~mA}$. 
Table 3. Test Results on The Second Day

\begin{tabular}{ccccc}
\hline Time & $\begin{array}{c}\text { Voltage Output } \\
\text { Generator }\end{array}$ & $\begin{array}{c}\text { Voltage Output } \\
\text { Buck-Boost } \\
\text { Converter }\end{array}$ & $\begin{array}{c}\text { Speed Of } \\
\text { Generator }\end{array}$ & $\begin{array}{c}\text { Current } \\
\text { Generator }\end{array}$ \\
\hline 08.00 & $8 \mathrm{~V}$ & $13.8 \mathrm{~V}$ & $412 \mathrm{Rpm}$ & $420 \mathrm{~mA}$ \\
09.00 & $8 \mathrm{~V}$ & $13.8 \mathrm{~V}$ & $432 \mathrm{Rpm}$ & $430 \mathrm{~mA}$ \\
10.00 & $8.5 \mathrm{~V}$ & $13.8 \mathrm{~V}$ & $478 \mathrm{Rpm}$ & $445 \mathrm{~mA}$ \\
11.00 & $10.2 \mathrm{~V}$ & $13.8 \mathrm{~V}$ & $511 \mathrm{Rpm}$ & $596 \mathrm{~mA}$ \\
12.00 & $9.8 \mathrm{~V}$ & $13.8 \mathrm{~V}$ & $495 \mathrm{Rpm}$ & $574 \mathrm{~mA}$ \\
13.00 & $9.5 \mathrm{~V}$ & $13.8 \mathrm{~V}$ & $534 \mathrm{Rpm}$ & $565 \mathrm{~mA}$ \\
14.00 & $10.6 \mathrm{~V}$ & $13.8 \mathrm{~V}$ & $515 \mathrm{Rpm}$ & $613 \mathrm{~mA}$ \\
15.00 & $10 \mathrm{~V}$ & $13.8 \mathrm{~V}$ & $592 \mathrm{Rpm}$ & $587 \mathrm{~mA}$ \\
16.00 & $9 \mathrm{~V}$ & $13.8 \mathrm{~V}$ & $465 \mathrm{Rpm}$ & $495 \mathrm{~mA}$ \\
\hline
\end{tabular}

From Table 4, the generator works optimally during the day at 15.00 with the resulting voltage of $10.6 \mathrm{~V}$, the generator rotation speed of $623 \mathrm{Rpm}$, and the current flowing is $603 \mathrm{~mA}$.

Table 4. Test Results on The Third Day

\begin{tabular}{ccccc}
\hline Time & $\begin{array}{c}\text { Voltage Output } \\
\text { Generator }\end{array}$ & $\begin{array}{c}\text { Voltage Output } \\
\text { Buck-Boost } \\
\text { Converter }\end{array}$ & $\begin{array}{c}\text { Speed Of } \\
\text { Generator }\end{array}$ & $\begin{array}{c}\text { Current } \\
\text { Generator }\end{array}$ \\
\hline 08.00 & $8,1 \mathrm{~V}$ & $13,8 \mathrm{~V}$ & $390 \mathrm{Rpm}$ & $408 \mathrm{~mA}$ \\
09.00 & $8.5 \mathrm{~V}$ & $13.8 \mathrm{~V}$ & $396 \mathrm{Rpm}$ & $413 \mathrm{~mA}$ \\
10.00 & $8.8 \mathrm{~V}$ & $13.8 \mathrm{~V}$ & $410 \mathrm{Rpm}$ & $456 \mathrm{~mA}$ \\
11.00 & $9 \mathrm{~V}$ & $13.8 \mathrm{~V}$ & $587 \mathrm{Rpm}$ & $535 \mathrm{~mA}$ \\
12.00 & $8.7 \mathrm{~V}$ & $13.8 \mathrm{~V}$ & $511 \mathrm{Rpm}$ & $502 \mathrm{~mA}$ \\
13.00 & $9.6 \mathrm{~V}$ & $13.8 \mathrm{~V}$ & $573 \mathrm{Rpm}$ & $545 \mathrm{~mA}$ \\
14.00 & $9.4 \mathrm{~V}$ & $13.8 \mathrm{~V}$ & $596 \mathrm{Rpm}$ & $524 \mathrm{~mA}$ \\
15.00 & $10.6 \mathrm{~V}$ & $13.8 \mathrm{~V}$ & $623 \mathrm{Rpm}$ & $603 \mathrm{~mA}$ \\
16.00 & $9,3 \mathrm{~V}$ & $13,8 \mathrm{~V}$ & $568 \mathrm{Rpm}$ & $511 \mathrm{~mA}$ \\
\hline
\end{tabular}


The next stage is battery testing. This battery charging test aims to find out how long the battery can be fully charged. The results of the battery charging test can be seen in table 5

Table 5. Battery Charging Test Results

\begin{tabular}{cccc}
\hline No & Volt & Current & Charging \\
\hline 1 & $13,8 \mathrm{~V}$ & $0,4 \mathrm{~A}$ & 10 Hour \\
2 & $13,8 \mathrm{~V}$ & $0,5 \mathrm{~A}$ & 8,5 Hour \\
3 & $13,8 \mathrm{~V}$ & $0,6 \mathrm{~A}$ & 7 Hour \\
\hline
\end{tabular}

\section{CONCLUSION}

This study aims to create and test the performance of the wave power generator design. The test location is in Talang Siring, Montok Village, Larangan District, Pamekasan Regency, East Java. Testing the design of the wave power plant is to work optimally during the day with the resulting voltage of $10.6 \mathrm{~V}$ and $10.7 \mathrm{~V}$ with a generator speed of 623 to $710 \mathrm{Rpm}$.

\section{REFERENCES}

[1] Direktorat Jendral Keteagalistrikan. 2019. Kebutuhan Energi Listrik Indonesia dan Statistik Ketenagalistrikan Indonesia. No. 30.

[2] Lubis, Abubakar. 2007. Energi Terbarukan Dalam Pembangunan Berkelanjutan. Badan Pengkajian dan Penerapan Teknologi. Vol 08. No. 02, Mei 2007.

[3] Muslim, Supari dan Joko. 2009. Teknik Perancangan Dan Instalasi Listrik. Universitas Negeri Surabaya, Indonesia.

[4] Machali, Imam. 2016. Metode Penelitian Kuantitatif. Yogyakarta : MPI Fakultas Ilmu Tarbiyah dan Keguruan UIN Sunan Kalijaga Yogyakarta.

[5] Aribowo, Widi. 2018. "Tuning For Power System Stabilizer Using Distributed Time-Delay Neural Network”. Sinergi,22(3).

[6] Aribowo, Widi. Supari Muslim. 2020. "Long-Term Electricity Load Forecasting Based On Cascade Forward Backpropagation Neural Network". Journal of Telecommunication, Electronic and Computer Engineering (JTEC), 12(2).

[7] Arifin, Moh. Zaenal. 2017. "Analisa Unjuk Kerja dan Tingkat Kavitasi Pada Turbin Francis di PT PJB Unit Pembangkitan Brantas Unit PLTA Sutami”. Diploma Thesis. Institut Teknologi Sepuluh Nopember.

[8] Dimas, Arya. 2019. "Prototype Pembangkit Listrik Tenaga Angin Menggunakan Generator DC Di Pelabuhan Tanjung Perak Surabaya”. Jurnal Teknik Elektro, 8(2). 
[9] Faharuddin, Andi, dkk. 2019. "Model Pembangkit Listrik Tenaga Ombak. Makassar". VERTEX ELEKTRO, 1(2).

[10] Kasharjanto, Afian. 2017. "Kajian Pemanfaatan Energi Arus Air Laut Di Indonesia”. Balai Teknologi Hidrodinamika BPPT, 11(2).

[11] Muchlis. 2003. Proyeksi Kebutuhan Listrik PLN Tahun 2003-2020. Laporan Penelitian, Proyeksi Listrik Indonesia, 2003.

[12] Nurdianto, Agus. 2020. Rancang Bangun Prototype Pembangkit Listrik Tenaga Angin Menggunakan Turbin Angin Sovonius. Jurnal Teknik Elektro, 9(1), 2020.

[13] Setiawan, David. 2018. Perancangan Dan Implementasi Prototype Pembangkit Listrik Tenaga Micro Hidro (PLTMH). Jurnal Teknik Elektro, 7(1).

[14] W. Ali, H. Farooq, A. ur Rehman dan M. E. Farrag. 2017. "Modeling and performance analysis of micro-hydro generation controls considering power system stability". First International Conference on Latest trends in Electrical Engineering and Computing Technologies (INTELLECT), Karachi, 2017, pp. 1-7, doi: 10.1109/INTELLECT.2017.8277626. 